\title{
Characterisation of Hanseniaspora Isolates with Potential Aroma- enhancing Properties in Muscat Wines
}

\author{
S. López, J.J. Mateo, S. Maicas* \\ Departament de Microbiologia i Ecologia, Universitat de València, Dr. Moliner, 50. E-46100, Burjassot, Spain
}

Submitted for publication: March 2014

Accepted for publication: April 2014

Key words: Hanseniaspora, $\beta$-glucosidase, $\beta$-xylosidase, yeast, wine, enzyme

\begin{abstract}
The sensorial characteristics of the wines produced with Muscat grapes are related to the level of terpene alcohols, so an improvement of such a level is expected as a result of hydrolytic processes conducted by Hanseniaspora. The aim of this work was to select and identify new strains for this purpose. In a second step, the strains were assayed to evaluate their oenological abilities. $H$. uvarum $\mathrm{H} 107$ and $H$. vineae G26 and P38 were proven to be good candidates to be used in commercial vinification processes to enhance wine properties. Wine inoculated with yeasts showed an increase in the level of aromatic compounds.
\end{abstract}

\section{INTRODUCTION}

Hanseniaspora, which are yeasts mainly found in soil, on fruits and trees and in spoiled foods and beverages, are characterised by apiculate cells and undergo vegetative reproduction by bipolar budding in basipetal succession. There are several species in the genus Hanseniaspora (Cadez et al., 2003; Jindamorakot et al., 2009; Kurtzman et al., 2011). They are physiologically very similar (Kurtzman \& Robnett, 1998): they ferment glucose, assimilate a few carbon compounds (arbutin, cellobiose, glucose, glucono- $\boldsymbol{\delta}$-lactone and salicin), and require inositol for growth (Kurtzman et al., 2011). The identification of yeast species has traditionally been based on assimilation and fermentation tests and morphological traits. These studies must be accompanied by other assays to assess a correct and unambiguous identification of the yeast. Molecular methods have been used to explore this yeast biodiversity, conferring a high degree of accuracy in the final identification (Kurtzman et al., 1994, 2011; Guillamón et al., 1998; Esteve-Zarzoso et al., 1999; Arroyo-López et al., 2006).

From a biotechnological point of view, although these yeasts can produce spoilage of fruits (Arroyo-López et al., 2008), they also possess many interesting technological properties (Charoenchai et al., 1997; Strauss et al., 2001; Maicas \& Mateo, 2005). In this way, exocellular enzymes of relative yeast species in different ecosystems have previously been reviewed (Mateo et al., 2011). Winemaking has been the process more deeply studied regarding the influence of Hanseniaspora (H. guilliermondii, H. uvarum, H. osmophila and $H$. vineae) and other non-Saccharomyces species. The modification of the characteristics of the wine is attributed to the capacity of certain non-Saccharomyces yeasts to produce and secrete hydrolytic enzymes that are able to transform grape compounds (Pando et al., 2012). These compounds are present in varying amounts as non-volatile flavour glycosylated precursors (Ugliano, 2009), mainly the disaccharides 6-O- $\alpha$-L-arabinofuranosyl- $\beta$-D-glucopyranoside, 6-O- $\alpha$-L-rhamnopyranosyl- $\beta$-D-glucopyranoside, $2-\mathrm{O}$ $\beta$-D-xylosyl-D-glucopyranoside and 6-O- $\beta$-L-apiofuranosil$\beta$-D-glucopyranoside (Mateo et al., 2011). The action of enzymes produced by wine yeasts, i.e. $\beta$-glucosidase or $\beta$-xylosidases, can contribute to liberate flavour from these compounds (Romano et al., 2003). Several groups have already made trial fermentations to study the compounds generated by Hanseniaspora (Paraggio, 2004; Arévalo et al., 2007; Swangkeaw et al., 2011).

The aim of the present study was to select and correctly identify Hanseniaspora strains to be used further as a source of enzymes in the winemaking industry and in other biotechnological processes. These yeasts are non-pathogenic and are recognised as safe organisms (GRAS) that can be used for the production of a variety of enzymes. Finally, our assays proved the benefits of using these yeasts to increase the level of terpenes in Muscat wine.

\section{MATERIALS AND METHODS \\ Yeast strains}

Grape juice and wine samples were collected from cellars in the D.O. Utiel-Requena (Eastern Spain) over the last 22 years (Mateo et al., 1991, 1992, 2011; Gil et al., 1996). Samples were stored at $-20^{\circ} \mathrm{C}$ and routinely spread onto malt agar (20 g/L malt extract, $1 \mathrm{~g} / \mathrm{L}$ peptone, $20 \mathrm{~g} / \mathrm{L}$ glucose, $20 \mathrm{~g} / \mathrm{L}$ agar) and grown at $28^{\circ} \mathrm{C}$ for viability check, or in YPD $(20 \mathrm{~g} / \mathrm{L}$ yeast extract, $10 \mathrm{~g} / \mathrm{L}$ peptone, $20 \mathrm{~g} / \mathrm{L}$ glucose) for routine assays. A total of 31 strains of Hanseniaspora yeast from our collection that previously were selected by using lysine

*Corresponding author: sergi.maicas@uv.es [Tel.: + 3496354 3214; Fax: + 3496354 4570]

Acknowledgements: This work was supported by a grant from INV-AE112-66049/UV. The authors wish to thank the technical staff of the wineries de Turis and Bodegas y Destilerias Vidal, which provided the wine samples. This research has been performed within the Program VLC/Campus, Microcluster IViSoCa. English text corrected by M. Maluenda 
agar as differential medium (Heard \& Fleet, 1986) were used in this study (Table 1). Isolates were identified according to their morphological and physiological characteristics as described by Kurtzman et al. (2011), and further verified by sequencing of the D1/D2 domain of 26S rDNA, as described by Kurtzman and Robnett (1998). Moreover, the Rapid ID Yeast Plus System (Remel, Lenexa, KS) was used to assess the strain-specific pattern of carbon compound assimilation, and other phenotypic assays (strain typing) according to the manufacturer's instructions.

\section{Qualitative screening of the biochemical activities $\beta$-Glucosidase activity}

The basal medium consisted of $1.7 \mathrm{~g} / \mathrm{L}$ yeast nitrogen base (Difco), $5 \mathrm{~g} / \mathrm{L}$ ammonium sulphate, $5 \mathrm{~g} / \mathrm{L}$ glucose and $20 \mathrm{~g} / \mathrm{L}$ agar. After autoclaving, $2 \mathrm{~mL}$ of a sterile $1 \%(\mathrm{w} / \mathrm{v})$ 4-methylumbelliferyl- $\beta$-D-glucopyranoside (Sigma-Aldrich, St. Louis, MO) was added to $100 \mathrm{~mL}$ of melted medium (Manzanares et al., 1999). The medium was then poured into Petri dishes and inoculated with $24 \mathrm{~h}$-old yeast cultures. Plates were incubated at $28^{\circ} \mathrm{C}$ for three days. The presence of enzymatic activity was visualised as a fluorescent halo surrounding yeast growth by plate exposure to UV light.

\section{Xylanase activity}

Xylanase production was determined according to Hernández at al. (2007) by spreading yeast colonies onto agar plates containing $5 \mathrm{~g} / \mathrm{L}$ xylan, $5 \mathrm{~g} / \mathrm{L}$ peptone and $5 \mathrm{~g} / \mathrm{L} \mathrm{NaCl}$. Plates were incubated at $28^{\circ} \mathrm{C}$ for seven days. A clear zone around the colony was indicative of xylanase activity.

\section{Pectinase and polygalacturonase activities}

The assays were carried out in the following medium: $1 \mathrm{~g} / \mathrm{L}$ yeast extract, $1 \mathrm{~g} / \mathrm{L}$ ammonium sulphate, $6 \mathrm{~g} / \mathrm{L} \mathrm{NaHPO}_{4}$, $3 \mathrm{~g} / \mathrm{L} \mathrm{KH} \mathrm{PO}_{4}, 5 \mathrm{~g} / \mathrm{L}$ pectin (for pectinase activity) or $5 \mathrm{~g} / \mathrm{L}$ polygalacturonic acid (for polygalacturonase activity), $15 \mathrm{~g} / \mathrm{L}$ agar. After streaking $48 \mathrm{~h}$-old yeast cultures onto the surface of the medium, the plates were incubated at $28^{\circ} \mathrm{C}$ for five days and then revealed by the addition of a solution of hexadecyltrimethylammonium bromide $(1 \mathrm{~g} / \mathrm{L})$, according to the procedure described by Oliveira et al. (2009). Both activities were evident from the presence of a clear halo around the colonies.

\section{Lipase and esterase activities}

Yeast isolates were used to determine esterase and lipase activity on tributyrin and rhodamine olive oil agar media respectively, according to the previously described procedures (Rodríguez et al., 2010; Madrigal et al. 2013). After $48 \mathrm{~h}$ of incubation in the media at $28^{\circ} \mathrm{C}$, the colonies were investigated. For the detection of lipase activity they were irradiated with UV light at $350 \mathrm{~nm}$; lipase activity was detected by an orange fluorescent halo around colonies. Esterase activity was detected by the formation of a clear transparent halo around colonies.

Saccharomyces cerevisiae CECT11783 and Candida molischiana ATCC 2516 were used as a positive control for polygalacturonase and $\beta$-glucosidase production respectively. Lipase from $C$. antarctica, esterase from $S$. cerevisiae and pectinase from Aspergillus niger were purchased from Sigma-Aldrich, St. Louis, MO for the same purpose. All the biochemical activities previously described were assayed in triplicate.

\section{Quantitative spectrophotometric assays $\beta$-Glucosidase and $\beta$-xylosidase activities}

$\beta$-Glucosidase and $\beta$-xylosidase activities were basically assayed using 4-nitrophenyl- $\beta$-D-glucopyranoside and 4 -nitrophenyl- $\beta$-D-xylopyranoside as the substrates (Romero et al., 2012). The yeasts were centrifuged and resuspended in $750 \mu \mathrm{L}$ of $0.2 \mathrm{M}$ citrate- $0.1 \mathrm{M}$ phosphate buffer ( $\mathrm{pH}$ 5.0). Then $250 \mu \mathrm{L}$ of $5 \mathrm{mM} p \mathrm{NP}$ substrate in the same buffer were added and the mixture was incubated at $40^{\circ} \mathrm{C}$ for $90 \mathrm{~min}$. The reaction was stopped by adding $1.0 \mathrm{~mL}$ of $0.2 \mathrm{MNa}_{2} \mathrm{CO}_{3}$, and absorbance at $404 \mathrm{~nm}$ was measured. Activity was expressed as nanokatals $(1 \mathrm{nkat}=1 \mathrm{nmol}$ of $p \mathrm{NP}$ liberated in one hour by $10^{6}$ yeast cells). Assays were performed in triplicate.

\section{Effect of sugars and ethanol on $\beta$-glucosidase and $\boldsymbol{\beta}$-xylosidase activities}

The effects of sugar on enzyme activities were conducted by using sugar concentrations over a range of 0 to $500 \mathrm{mM}$ (glucose and fructose) or 0 to $50 \mathrm{mM}$ (sucrose). The effect of ethanol (Merck, Darmstadt, Germany) on enzyme activity was determined by using ethanol concentration over a range of 0 to $20 \%(\mathrm{v} / \mathrm{v})$. The enzyme assays were carried out as described previously.

Effect of temperature and $\mathrm{pH}$ on $\beta$-glucosidase and $\boldsymbol{\beta}$-xylosidase activities

The $\mathrm{pH}$ optimum was determined in $0.2 \mathrm{M}$ citrate- $0.1 \mathrm{M}$ phosphate buffer, covering a $\mathrm{pH}$ range from 3.0 to 8.0 , at

TABLE 1

Hanseniaspora yeast isolates from the Utiel-Requena region.

\begin{tabular}{|c|c|c|c|}
\hline Yeast species & $\begin{array}{l}\text { Number of } \\
\text { isolates }\end{array}$ & $\begin{array}{l}\text { Matching } \\
\text { nucleotides }(\%)^{\mathrm{a}}\end{array}$ & Collection number \\
\hline $\begin{array}{l}\text { Hanseniaspora } \\
\text { uvarum }\end{array}$ & 18 & $99.4-99.6 \%$ & $\begin{array}{l}\text { E18, E20, E44, F42, G09, G89, H03, H105, H106, H107, H156, } \\
\text { H172, B21, B95, M45, M46, M47, M48 }\end{array}$ \\
\hline H. vineae & 4 & $99.5-99.6 \%$ & E71, G26, P30, P38 \\
\hline H. guilliermondii & 8 & $99.6-99.8 \%$ & A27, A29, B02, B04, C06, D55, D56, D57 \\
\hline H. osmophila & 1 & $99.7 \%$ & $\mathrm{C} 07$ \\
\hline Total & 31 & & \\
\hline
\end{tabular}

${ }^{a}$ Sequence identity in the D1/D2 region of 26S ribosomal genes and closest relative species in the NCBI GenBank database. 
$40^{\circ} \mathrm{C}$ for $90 \mathrm{~min}$. The temperature optimum was measured from $4^{\circ} \mathrm{C}$ to $60^{\circ} \mathrm{C}$ for $90 \mathrm{~min}$ of incubation in the same buffer, at $\mathrm{pH}$ 5.0. The residual activities were determined.

\section{Winemaking}

Muscat juice (1 $000 \mathrm{hL}$ ) was fermented using $30 \mathrm{~g} / \mathrm{hL}$ commercial wine yeast strain $S$. cerevisiae QA23 (Lalvin, Lallemand, Montreal, Canada). Fermentation was carried out at 16 to $24^{\circ} \mathrm{C}$. Must sampling for the analysis of sugar concentrations was performed weekly. After 23 days, when less than $2 \mathrm{~g} / \mathrm{L}$ residual sugar remained, the wine was separated from the gross lees. Samples were collected and stored at $4^{\circ} \mathrm{C}$ for the second inoculation with Hanseniaspora. This wine, provided by the Baronía de Turís winery, was as follows: ethanol, $13.3 \% \mathrm{v} / \mathrm{v} ; \mathrm{pH}, 3.33$; titratable acidity, $3.6 \mathrm{~g} / \mathrm{L}$; volatile acidity, $0.35 \mathrm{~g} / \mathrm{L}$; malic acid, $1.0 \mathrm{~g} / \mathrm{L}$. The wine was sterilised by $0.45 \mu \mathrm{m}$ filtration and sterility was verified by spreading $100 \mu \mathrm{L}$ wine on YPD plates.

\section{Determination of volatile compounds liberated from wine incubated with Hanseniaspora strains}

$H$. uvarum $\mathrm{H} 107$ and $H$. vineae $\mathrm{G} 26$ and $\mathrm{P} 38$ were grown in YPD, centrifuged, resuspended in distilled water, added to $400 \mathrm{~mL}$ Muscat wine at a final concentration of $1.0 \times$ $10^{6} \mathrm{cfu} / \mathrm{mL}$, and incubated in separated $500 \mathrm{~mL}$ cottonplugged flasks at $20^{\circ} \mathrm{C}$ for 14 days, without shaking. Wine produced with $S$. cerevisiae, without added Hanseniaspora yeasts, was assayed in parallel to act as a control. The isolation of terpenes was then carried out on C18 SPE columns (Waters, Milford, MA). A total of $250 \mathrm{~mL}$ of each wine was eluted through the columns, previously activated with $30 \mathrm{~mL}$ of methanol (Merck, Darmstadt, Germany), and followed by $50 \mathrm{~mL}$ of water. The cartridge was washed with $100 \mathrm{~mL}$ of water and lipophilic compounds (terpenes) were eluted with $50 \mathrm{~mL}$ of dichloromethane (Merck). Volatile compounds were determined by using an Agilent $6890 \mathrm{~N}$ gas chromatograph-5973N mass detector system. The chromatograph was equipped with a HP-20M fused silica capillary column $(50 \mathrm{~m} \times 0.32 \mathrm{~mm}$ i.d., $0.3 \mu \mathrm{m}$ film thickness). The splitless injector was maintained at $250^{\circ} \mathrm{C}$. Helium was used as carrier gas (inlet pressure $10.5 \mathrm{psi}$ ) and the interface temperature was $230^{\circ} \mathrm{C}$. The oven was held isothermally at $30^{\circ} \mathrm{C}$ for $1 \mathrm{~min}$ and then increased to $60^{\circ} \mathrm{C}$ at $30^{\circ} \mathrm{C} / \mathrm{min}$. The oven temperature was programmed from $60^{\circ} \mathrm{C}$ to $120^{\circ} \mathrm{C}$ at $3^{\circ} \mathrm{C} / \mathrm{min}$, and then to $220^{\circ} \mathrm{C}$ at $2^{\circ} \mathrm{C} / \mathrm{min}$. 1 -Heptanol $(1 \mathrm{mg} / \mathrm{mL})$ was used as internal standard.

\section{Statistical analyses}

The volatile compounds were subjected to one factor analysis of variance (ANOVA, Statbox software). The results were considered significant if the associated $P$ values were below 0.05 .

\section{RESULTS}

Identification and physiological characterisation of strains

The 218 non-Saccharomyces yeasts stored in our collection were investigated. A total of 31 isolates were presumptively identified as Hanseniaspora and used to carry out this work (Table 1). The ribosomal D1/D2 regions of these isolates were sequenced and, after screening for DNA homology using the BLAST program, yeast species identities were verified by comparing sequences of their ribosomal internal transcribed spacer regions (Cadez et al., 2002). We found isolates belonging to four oenological species of the genus $H$. uvarum (18), H. vineae (4), H. osmophila (1) and H. guillermondii (8) (Kurtzman \& Robnett, 1998).

The strain-specific pattern of carbon compound assimilation and other phenotypic assays (strain typing) were carried out using Rapid ID Yeast Plus. The results obtained with this commercial kit (Table 2) preliminarily suggested that none of the Hanseniaspora species used in this study had $\alpha$ galactosidase, $\beta$-galactosidase, phosphatase, phosphatidylcoliesterase or urease activities. Moreover, $\mathrm{N}$-acetyl-glucosamine and fatty acid esters were not assimilated. Some other differences were detected among strains. More accurate qualitative assays were further carried out to achieve better characterisation of biochemical activities.

\section{Qualitative assays of enzymatic activities}

The final results for the 31 Hanseniaspora strains characterised in this work are shown in Table 3. Similar patterns of overall enzyme activity were observed. Almost all strains displayed moderated or no lipase, esterase, polygalacturonase or pectinase activity. Moreover, a total of 28 strains showed $\beta$-glucosidase activity.

\section{$\beta$-glucosidase and $\beta$-xylosidase activities}

We examined our isolates to determine $\beta$-glucosidase and $\beta$-xylosidase activities, the two more relevant glycosidic activities for non-Saccharomyces yeasts in wine (Mateo \& Di Stefano, 1997; Fernández et al., 2000; Strauss et al., 2001; Mateo et al., 2011). H. uvarum $\mathrm{H} 107$ and H. vineae (G26 and P38) exhibited strong reactions in both the $\beta$-glucosidase and $\beta$-xylosidase quantitative assays ( $>30$ nkat) (Table 4$)$. These isolates were selected to quantify the level of production of these activities under oenological stress conditions, i.e. high sugar or ethanol concentrations.

\section{Effect of sugars or ethanol on $\beta$-glucosidase and $\beta$-xylosidase activities}

The effects of sugar concentration (glucose, fructose and sucrose) on $\beta$-glucosidase and $\beta$-xylosidase were assayed. The $\beta$-glucosidase and $\beta$-xylosidase activities of the three strains were not affected by fructose ( 0 to $500 \mathrm{mM})$ and sucrose $(0$ to $50 \mathrm{mM}$ ) (data not shown). The $\beta$-glucosidase activity of the three Hanseniaspora strains was slightly inhibited by low glucose concentrations (Fig. 1A). The enzyme retained 70 to $80 \%$ and 40 to $60 \%$ of relative activity in the presence of 50 and $100 \mathrm{mM}$ glucose respectively. Moreover, 30\% remaining activity was detected in the presence of $500 \mathrm{mM}$ glucose. Similar results were observed in the three assayed strains. The $\beta$-xylosidase activity results were similar (Fig. 1B). We also detected moderated inhibition at $50 \mathrm{mM}$ glucose, but 30 to $50 \%$ activity was retained at higher glucose concentrations (100 to $500 \mathrm{mM})$.

The effect of ethanol concentration in the range 0 to $20 \%(\mathrm{v} / \mathrm{v})$ on both glycolytic activities was also determined. The $\beta$-glucosidase activity from the three Hanseniaspora 
TABLE 2

Results of the RapID yeast plus assays. (-) No assimilation, $(+)$ assimilation

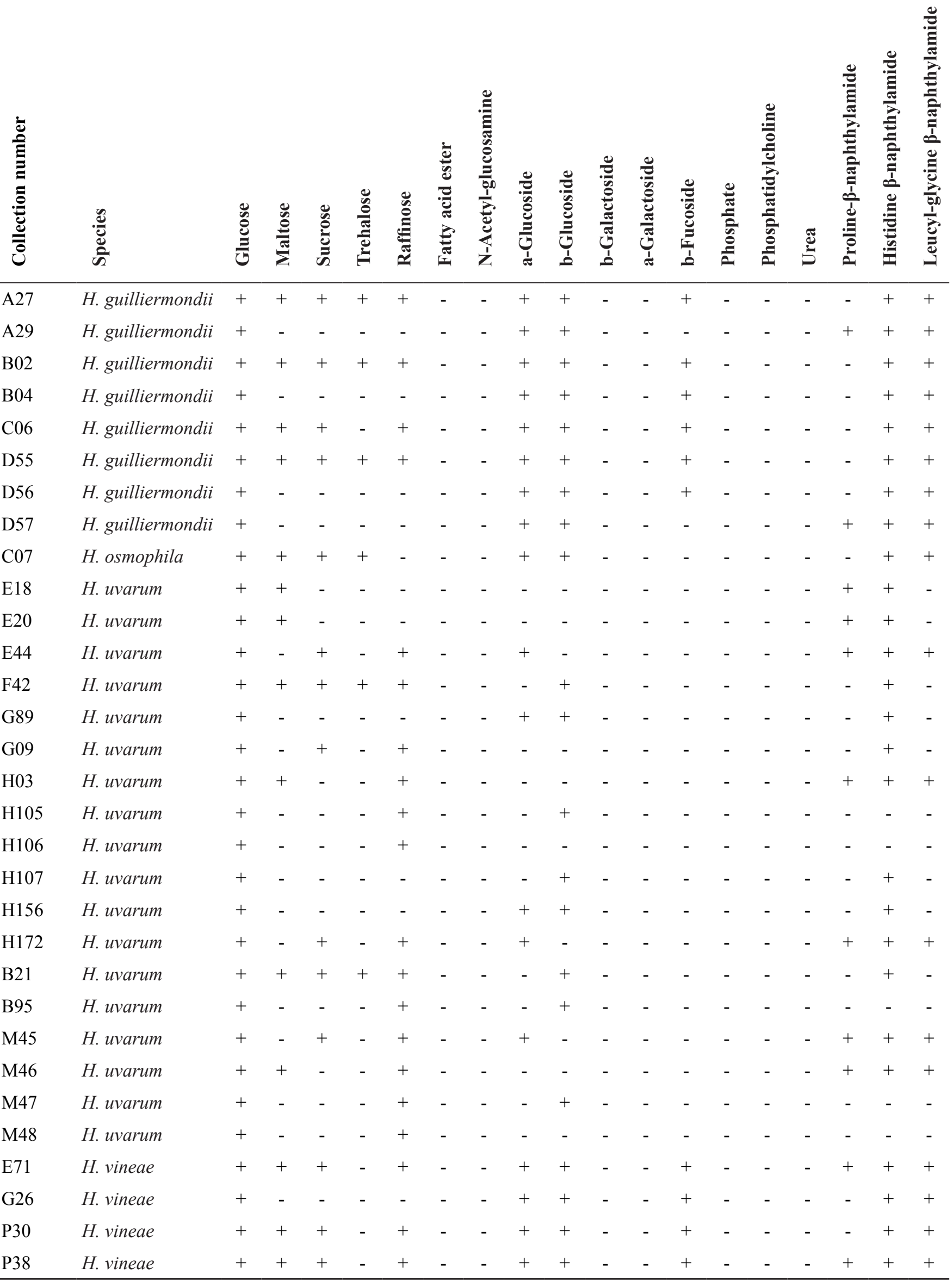


TABLE 3

Enzymatic activity of the Hanseniaspora strains.

\begin{tabular}{|c|c|c|c|c|c|c|c|c|c|c|c|c|c|c|c|c|c|c|c|}
\hline \multirow[t]{3}{*}{ Yeast } & \multirow{3}{*}{$\begin{array}{l}\text { Number } \\
\text { isolates }\end{array}$} & \multicolumn{18}{|c|}{ Enzymes level of activity ${ }^{a}$} \\
\hline & & \multicolumn{3}{|c|}{ Pectinase } & \multicolumn{3}{|c|}{ Esterase } & \multicolumn{3}{|c|}{ Lipase } & \multicolumn{3}{|c|}{$\begin{array}{c}\beta- \\
\text { glucosidase }\end{array}$} & \multicolumn{3}{|c|}{$\begin{array}{c}\text { Poly- } \\
\text { galacturonase }\end{array}$} & \multicolumn{3}{|c|}{ Xylanase } \\
\hline & & - & + & ++ & - & + & ++ & - & + & ++ & - & + & ++ & - & + & ++ & - & + & ++ \\
\hline H. uvarum & 18 & 12 & 6 & & 6 & 6 & & 8 & 10 & & & 6 & 12 & 14 & 4 & & 15 & 3 & \\
\hline H. vineae & 4 & 3 & 1 & & 1 & 1 & & 1 & 3 & & & & 4 & 1 & 3 & & 2 & 2 & \\
\hline H. guilliermondii & 8 & 6 & 2 & & 3 & 3 & & 8 & & & 3 & 1 & 3 & 5 & 3 & & 6 & 2 & \\
\hline H. osmophila & 1 & 1 & & & 1 & 1 & & 1 & & & & & 1 & 1 & & & 1 & & \\
\hline Total & 31 & 22 & 9 & & 11 & 20 & & 18 & 13 & & 3 & 8 & 20 & 21 & 10 & & 24 & 7 & \\
\hline
\end{tabular}

a Activity: (-), no activity; (+), moderate activity; (++), strong activity. Data obtained from triplicate assays

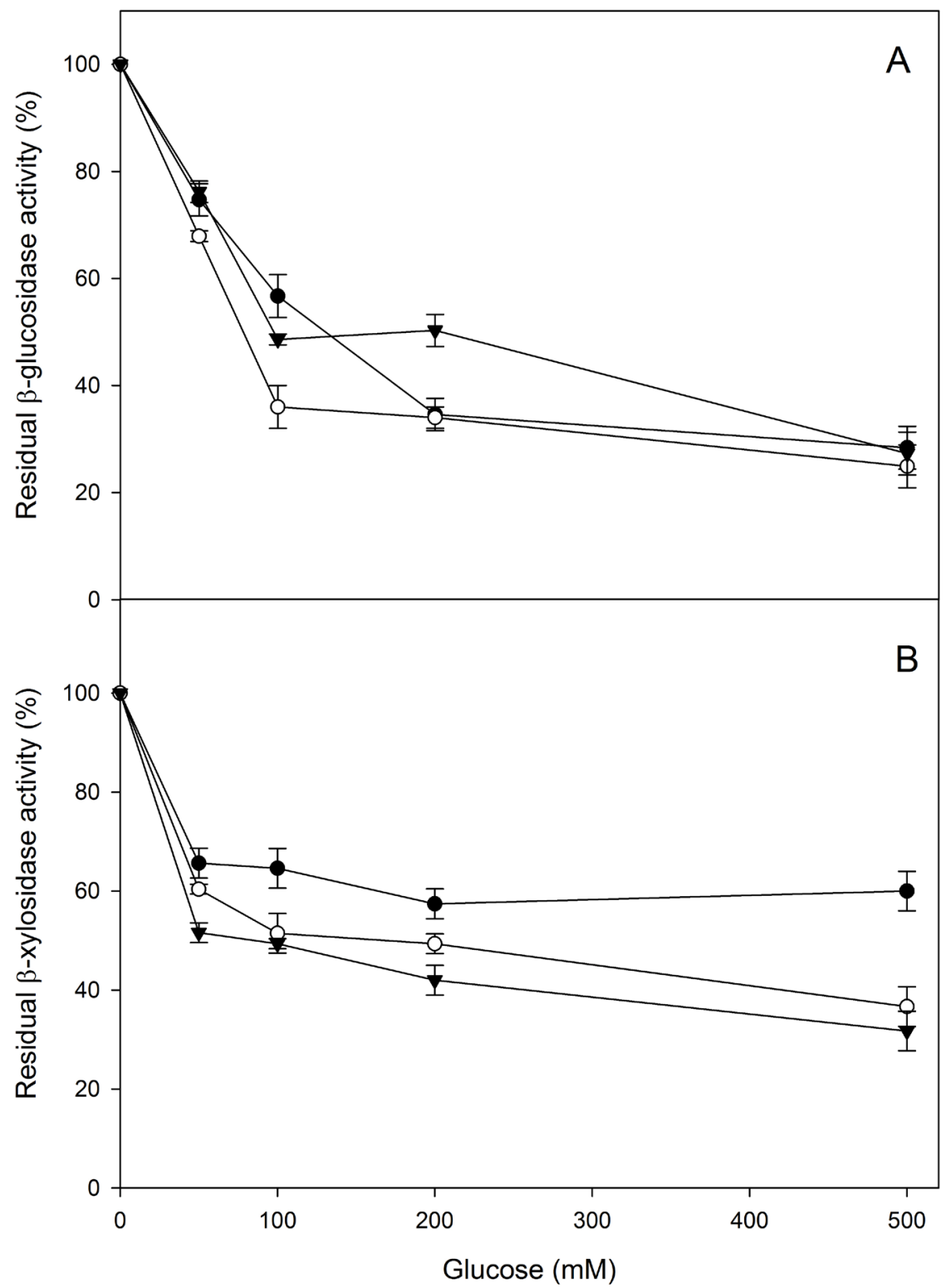

FIGURE 1

Effect of glucose concentration on glycolytic activities of different Hanseniaspora strains: (•) H. uvarum H107, (०) H. vineae G26, ( $\boldsymbol{\nabla}) H$. vineae P38. Enzyme activities were measured in the presence of various amounts of glucose under the standard assay conditions for A) $\boldsymbol{\beta}$-glucosidase and B) $\boldsymbol{\beta}$-xylosidase activities. Data represent means \pm standard deviations from triplicate assays. 
strains was slightly inhibited by low and medium ethanol concentrations ( 0 to $10 \%, \mathrm{v} / \mathrm{v}$ ) (Fig. 2A). In the presence of $20 \%$ (v/v) ethanol, 20 to $50 \%$ of activity remained. Similar results were expected from the $\beta$-xylosidases (Fig. 2B). The remaining activity of the three strains at $20 \%(\mathrm{v} / \mathrm{v})$ was similar (around 40\%).

\section{Effect of temperature and $\mathrm{pH}$ on $\beta$-glucosidase and} $\boldsymbol{\beta}$-xylosidase activities

The $\beta$-glucosidase activity did not vary with temperature ranging from $4^{\circ} \mathrm{C}$ to $60^{\circ} \mathrm{C}$ (Fig. $3 \mathrm{~A}$ ), with an optimum of $30^{\circ} \mathrm{C}$ to $40^{\circ} \mathrm{C}$. However, the $\beta$-xylosidase activity was highly influenced by temperature (Fig. 3B). Optimum temperature for the three strains was detected at $30^{\circ} \mathrm{C}$, showing percentages of activity lower than $40 \%$ at extreme values $\left(4^{\circ} \mathrm{C}\right.$ to $\left.60^{\circ} \mathrm{C}\right)$.

The $\mathrm{pH}$ optimum was also evaluated in phosphate buffer ranging from $\mathrm{pH} 3.0$ to 8.0 . The $\beta$-glucosidase activity of the three Hanseniaspora strains was influenced slightly inside the interval assay, with residual activities between $80 \%$ and $100 \%$ (Fig. 4A). $\beta$-Xylosidase exhibited high $\mathrm{pH}$ stability between $\mathrm{pH} 5.0$ and 8.0 , retaining more than $80 \%$ of residual activity in vitro, with an optimum value of around $\mathrm{pH} 6.0$ to 7.0 (Fig. 4B).

Determination of volatile compounds liberated from wine treated with different Hanseniaspora yeasts

Muscat juice was used for vinification with a commercial S. cerevisiae strain. Afterwards, H. uvarum $\mathrm{H} 107$ and $H$. vineae $\mathrm{G} 26$ and $\mathrm{P} 38$ were inoculated (in triplicate assays) and terpene compounds were determined (Table 5). We were not able to detect a significant increase in the level of nerol and geraniol after the addition of Hanseniaspora isolates. This can be attributed to the fact that the production of

TABLE 4

Glycolytic activities $\left(\mathrm{nmol} \mathrm{Pnp} / \mathrm{h} / 10^{6}\right.$ yeasts $\left.=\mathrm{nkat}\right)$ of the Hanseniaspora strains

\begin{tabular}{|c|c|c|c|}
\hline Isolate & Species & $\beta$-Xylosidase (nkat) ${ }^{a}$ & $\beta$-Glucosidase (nkat) ${ }^{\mathrm{a}}$ \\
\hline $\mathrm{A} 27$ & H. guilliermondii & $2.65 \pm 0.08$ & $1.70 \pm 0.17$ \\
\hline A29 & H. guilliermondii & $2.18 \pm 0.34$ & $8.09 \pm 0.22$ \\
\hline B02 & H. guilliermondii & $2.38 \pm 0.07$ & $21.07 \pm 0.11$ \\
\hline B04 & H. guilliermondii & $2.24 \pm 0.84$ & $4.83 \pm 0.23$ \\
\hline $\mathrm{C} 06$ & H. guilliermondii & $4.33 \pm 0.08$ & $5.27 \pm 0.21$ \\
\hline D55 & H. guilliermondii & $3.60 \pm 0.64$ & $36.10 \pm 0.13$ \\
\hline D56 & H. guilliermondii & $2.99 \pm 0.14$ & $20.80 \pm 2.23$ \\
\hline D57 & H. guilliermondii & $2.72 \pm 0.45$ & $6.66 \pm 0.26$ \\
\hline $\mathrm{C} 07$ & H. osmophila & $2.92 \pm 0.23$ & $5.91 \pm 0.89$ \\
\hline E18 & H. uvarum & $2.31 \pm 0.57$ & $3.06 \pm 0.84$ \\
\hline E20 & H. uvarum & $2.11 \pm 0.17$ & $42.49 \pm 0.43$ \\
\hline E44 & H. uvarum & $2.99 \pm 0.62$ & $2.99 \pm 0.11$ \\
\hline F42 & H. uvarum & $2.86 \pm 0.11$ & $3.26 \pm 0.56$ \\
\hline G89 & H. uvarum & $1.90 \pm 0.26$ & $2.92 \pm 0.19$ \\
\hline G09 & H. uvarum & $9.45 \pm 0.23$ & $40.38 \pm 0.64$ \\
\hline H03 & H. uvarum & $1.90 \pm 0.07$ & $2.58 \pm 0.05$ \\
\hline H105 & H. uvarum & $3.60 \pm 0.71$ & $5.64 \pm 0.34$ \\
\hline H106 & H. uvarum & $15.83 \pm 3.83$ & $16.36 \pm 3.16$ \\
\hline H107 & H. uvarum & $38.34 \pm 0.14$ & $48.74 \pm 2.83$ \\
\hline H156 & H. uvarum & $2.58 \pm 0.23$ & $5.30 \pm 0.23$ \\
\hline H172 & H. uvarum & $2.24 \pm 0.78$ & $21.89 \pm 2.98$ \\
\hline B21 & H. uvarum & $12.11 \pm 0.13$ & $8.06 \pm 0.32$ \\
\hline B95 & H. uvarum & $2.99 \pm 0.64$ & $20.08 \pm 0.11$ \\
\hline M45 & H. uvarum & $22.86 \pm 0.12$ & $4.63 \pm 0.24$ \\
\hline M46 & H. uvarum & $1.90 \pm 0.29$ & $3.26 \pm 0.82$ \\
\hline M47 & H. uvarum & $18.45 \pm 0.21$ & $2.91 \pm 0.39$ \\
\hline M48 & H. uvarum & $18.17 \pm 0.14$ & $5.24 \pm 0.24$ \\
\hline E71 & H. vineae & $2.86 \pm 0.19$ & $26.85 \pm 0.71$ \\
\hline G26 & H. vineae & $39.22 \pm 0.84$ & $48.81 \pm 0.78$ \\
\hline P30 & H. vineae & $2.72 \pm 0.51$ & $13.53 \pm 0.16$ \\
\hline P38 & H. vineae & $31.00 \pm 0.71$ & $51.26 \pm 3.11$ \\
\hline
\end{tabular}

${ }^{a}$ Average of duplicates 
these compounds could have been carried out previously by Saccharomyces strains during the alcoholic fermentation of Muscat wines (Mateo \& Di Stefano, 1997; Restuccia et al., 2002). The concentration of cis-5-vinyltetrahydro-1,1,5-trimethyl-2-furanmethanol was not increased, despite the addition of Hanseniaspora, while the other oxides (trans-5-vinyltetrahydro-1,1,5-trimethyl-2-furanmethanol, cis-6-vinyltetrahy-dro-2,2,6-trimethyl-2H-pyran-3-ol and trans-6-vinyltetrahydro-2,2,6-trimethyl-2H-pyran-3-ol) were not detected. Moreover, 2,6-dimethyl-2,7-octadien-1,6-diol levels were not affected.

Linalool and derivative compounds and aromatic alcohols were detected at the same level of the control wine, after the addition of Hanseniaspora isolates. Terpineol increased only after the addition of $H$. uvarum $\mathrm{H} 107$ or $H$. vineae G26, but not when $H$. vineae $\mathrm{P} 38$ was added. The same results were recorded for 4-vinyl-phenol and 2-methoxy-4-vinylphenol. Linalool, 2-phenyl ethanol and 4-vinyl-phenol compounds are associated with fruity characteristics (Maicas \& Mateo, 2005; López de Lerma \& Peinado, 2011).

The analysis of the other compounds revealed an increase in concentration when yeasts were added, therefore assessing the effect of glycosidases. Wines treated with Hanseniaspora showed higher concentrations of 2-phenyl ethanol (Gunata et al., 1988; Dubourdieu et al., 1989). H. uvarum H107 provides improvements in 2-phenylethyl acetate production, as previously reported for other Hanseniaspora strains (Rojas et al., 2001; Moreira et al., 2005; Viana et al., 2009).

\section{DISCUSSION}

The criteria for the discrimination of yeast species proposed by Kurtzman and Robnett (1998) using D1/D2 rDNA sequencing was used in this work: a match greater than $99 \%$ was required to discriminate among yeast species. The analysis of the miniaturised biochemical assay strips basically confirmed these results, although some other minor

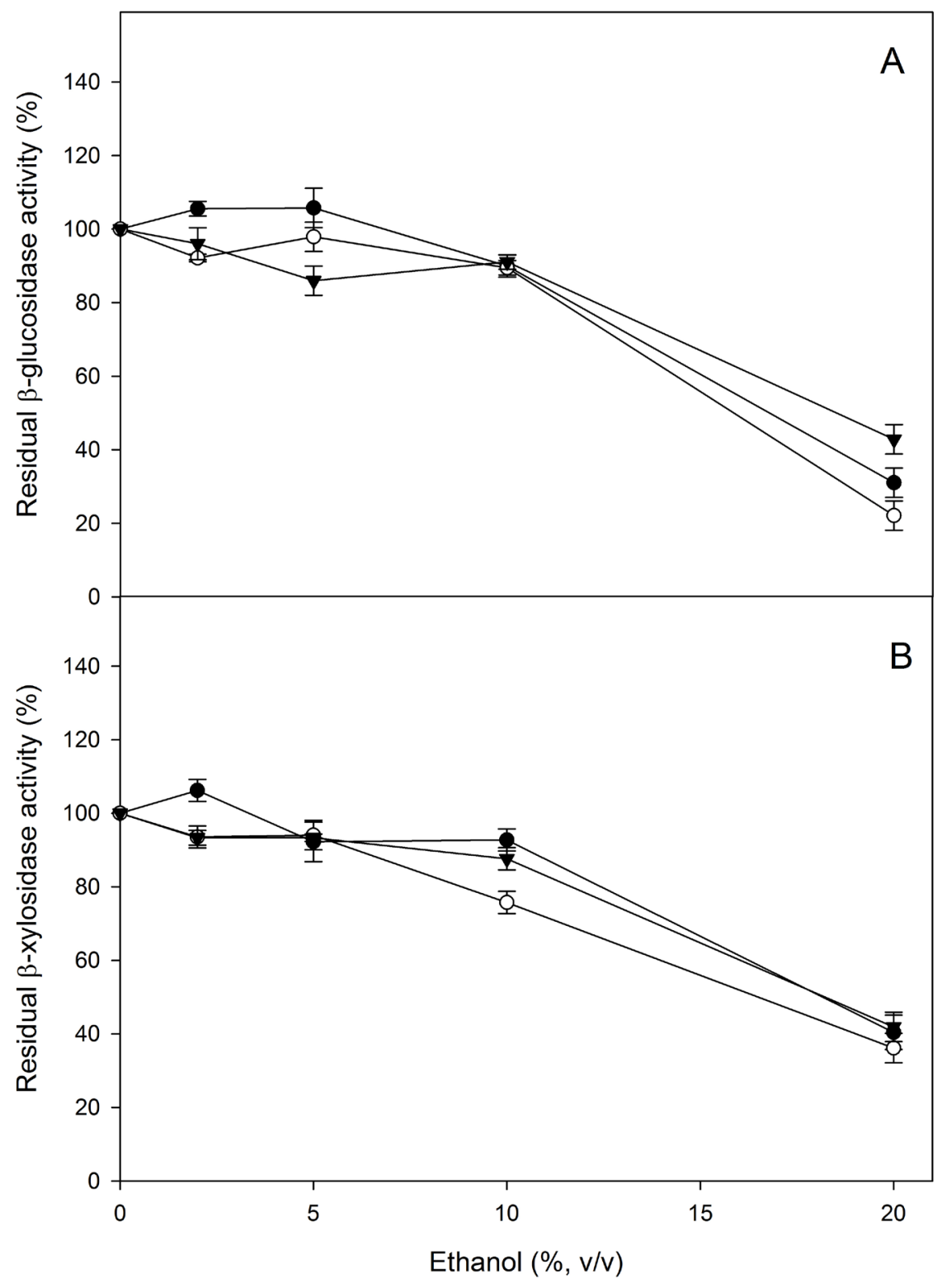

FIGURE 2

Effect of ethanol concentration on glycolytic activities of different Hanseniaspora strains. Legends are as shown in Fig. 1. 
differences were observed - probably due to strain rather than intraspecific differences. The use of these yeast identification tests, although in some cases species specific, can be used for a preliminary characterisation of the assimilation of carbon compounds (strain typing), rather than for identification purposes.

The role of microbial glycosidases in the hydrolysis of glycosides during the winemaking process was detected. From a technological point of view, this activity justifies the utilisation of Hanseniaspora in the industrial production of aromatic wines (Fernández-González et al., 2003; Mateo et al., 2011; Swangkeaw et al., 2011). However, yeasts belonging to the Hanseniaspora genus have been considered as spoilage yeasts, particularly during the first stage of fermentation, due to the undesirable production of compounds such as acetic acid or ethyl acetate (Ciani \& Comitini, 2011). The significance of glycosidases for the wine industry lies in their potential to release flavour compounds from glycosidically bound nonvolatile precursors in wine (Gueguen et al.,
1997; Ubeda \& Briones, 2000; Ferreira et al., 2001; Strauss et al., 2001; Maicas \& Mateo, 2005; Arévalo et al., 2007). Some aromatic precursors (terpenes) found in wine are not volatile and therefore cannot contribute to wine aroma. The Hanseniaspora strains included in this work showed $\beta$-glucosidase and $\beta$-xylosidase activities (remarkable H. uvarum $\mathrm{H} 107$ and $H$. vineae $\mathrm{G} 26$ and $\mathrm{P} 38$ ). To elucidate if wine conditions could affect their activity, as suggested by Grimaldi et al. (2005), we also studied the influence of sugar and ethanol addition to simulate native conditions in the wine. Our results were in agreement with Strauss et al. (2001), detecting a significant negative influence on the activities of $\beta$-glucosidase and $\beta$-xylosidase at high glucose concentration. This negative influence was greater than that exerted by the ethanol on the same enzymes, suggesting that they may be less effective in wine. These results also confirm data previously reported by our group in other nonSaccharomyces strains (Mateo et al., 2011; Romero et al., 2012). Our report is surprising, as Hanseniaspora is a genus

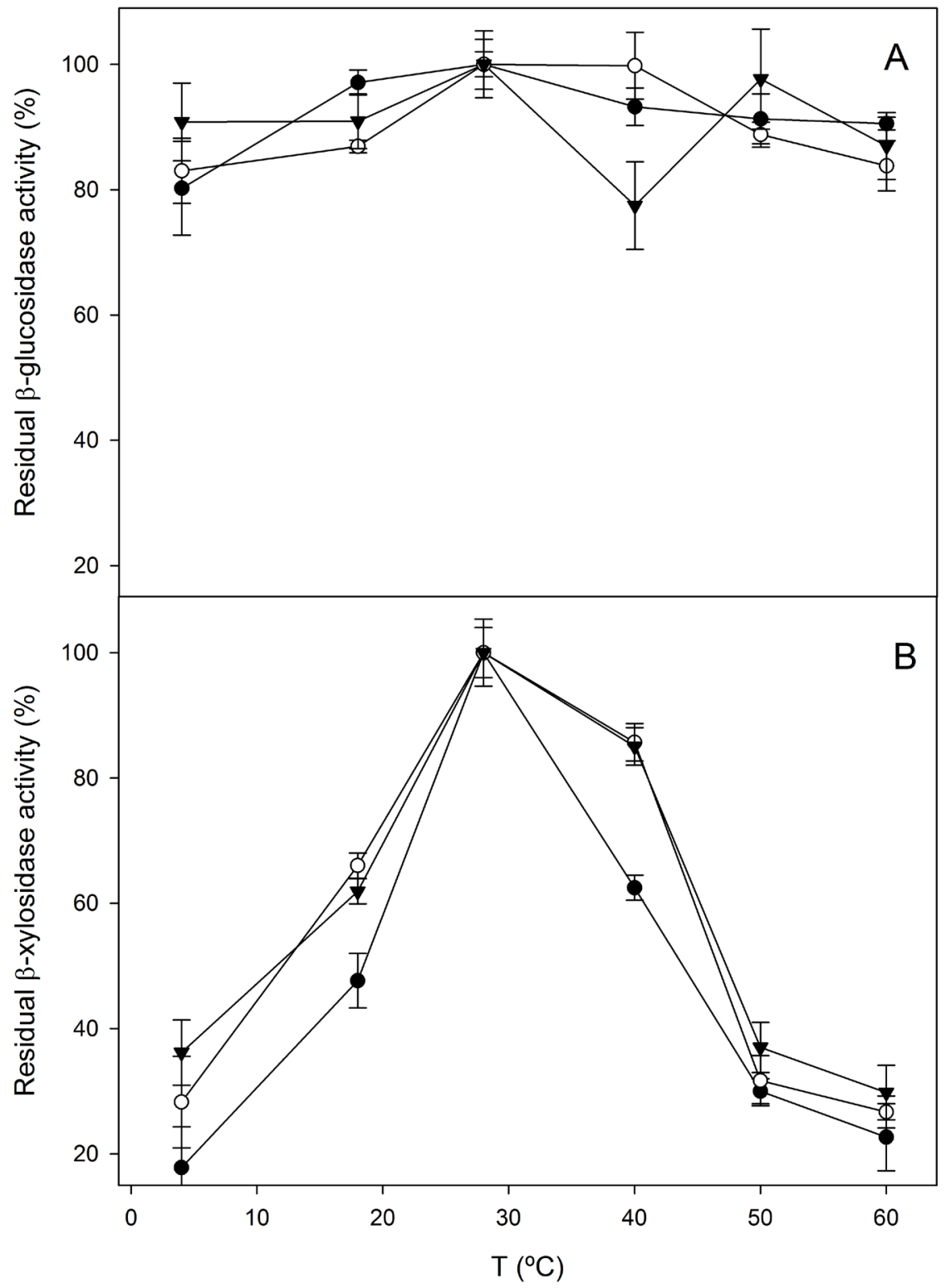

FIGURE 3

Effect of temperature on glycolytic activities of different Hanseniaspora strains. Legends are as shown in Fig. 1. 


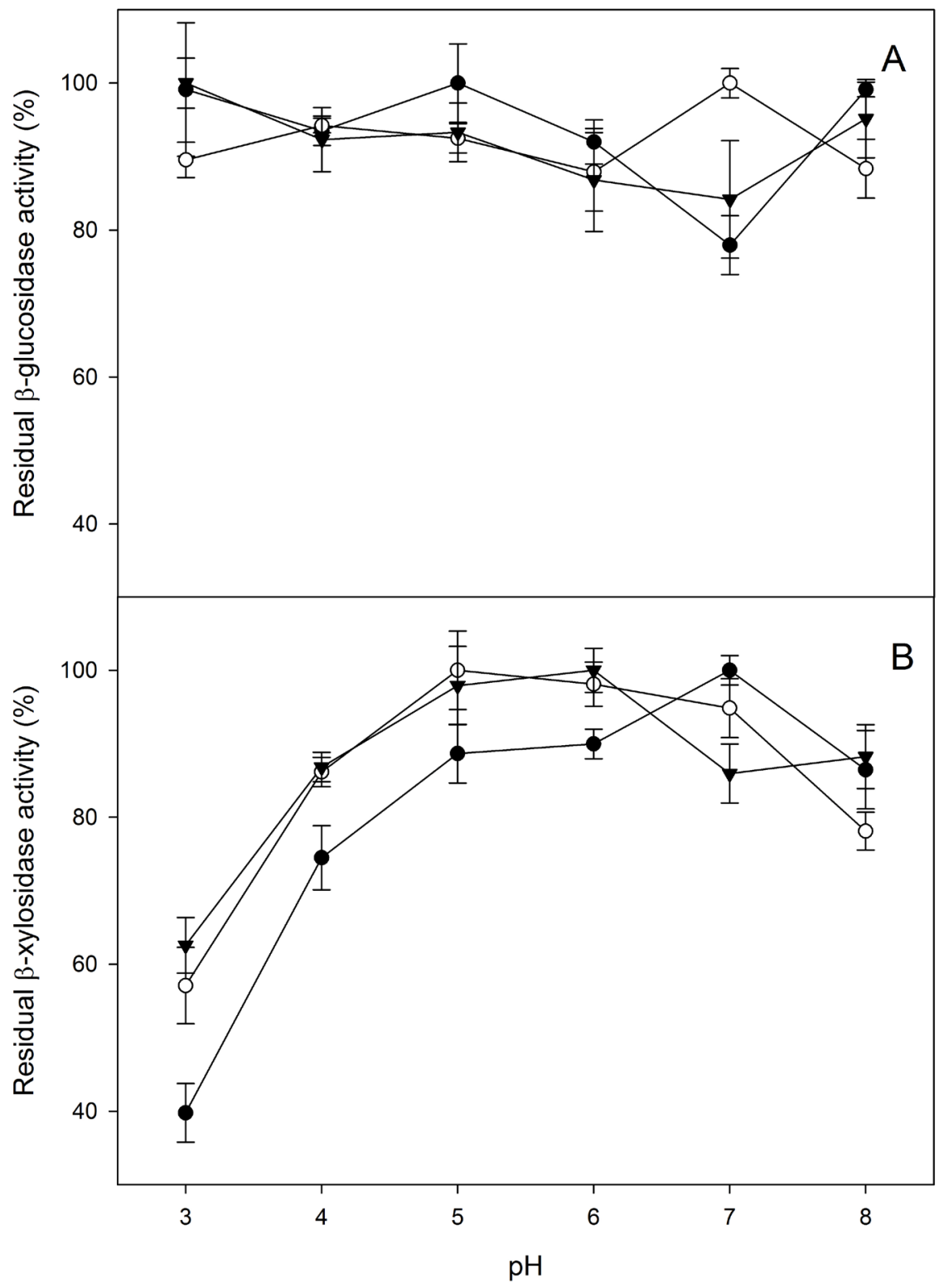

FIGURE 4

Effect of $\mathrm{pH}$ on glycolytic activities of different Hanseniaspora strains. Legends are as shown in Fig. 1.

described as ethanol inhibited in vivo (Branco et al., 2012). It has previously been reported that low quantities of alcohol stimulate $\beta$-glucosidase activity (Swangkeav et al., 2011). These results are similar to our findings for $\beta$-glucosidase, but mainly for $\beta$-xylosidase. Romero et al. (2012) argued that the glycosyltransferase activity of the enzyme could be conditioning this fact.

The $\beta$-glucosidase activity was not affected by temperature, while $\beta$-xylosidase activity was highly influenced. The first result is very important, because winemaking is now conducted at low temperatures, hence it is important to obtain enzymes with high activity under these conditions. The high activity of $\beta$-glucosidase at different values of $\mathrm{pH}$ also permits a broad interval of use. However, the $\beta$-xylosidase optimal range of use was at $\mathrm{pH} 5.0$ to 8.0. The residual activity, even at low $\mathrm{pH}$ (3.0 to 5.0), was good enough to permit use in wines at different $\mathrm{pH}$ values.

Monoterpenes, norisoprenoids, benzene derivatives and aliphatic components are traditionally involved in Muscat grape juice and wine. These compounds have been detected in the glycosidically bound form: therefore, their liberation could enhance wine aroma. In order to confirm our previous laboratory results, assays were also carried out in Muscat wine, and volatile compounds were analysed by GC/MS. Muscat wine $(13 \%, \mathrm{v} / \mathrm{v}$, initial alcohol) showed only a moderate overall increase in terpene (1.1- to 1.3 -fold) when treated with these strains. These results are conditioned by the effect of ethanol on glycolytic enzymes. Going into detail, the use of these strains offered an increase in the levels of ho-trienol, 2-phenylethanol and 2,6-dimethyl-3,7octadien-2,6-diol in the wine. The sum of ho-trienol, linalool and terpineol seems to play an important role in the aromatic definition of wines from the Loureiro and Alvarinho varieties (Oliveira et al., 2008). 2-Phenylethanol also participates to confer fruity and floral notes to these wines, and its presence is related to the metabolic activity of the non-Saccharomyces 
TABLE 5

Terpene compounds in Muscat wine. Concentration expressed as $\mu \mathrm{g} / \mathrm{L}^{\mathrm{a}}$.

\begin{tabular}{|c|c|c|c|c|}
\hline & \multirow[t]{2}{*}{ Control } & \multicolumn{3}{|c|}{ Hanseniaspora inoculated } \\
\hline & & H. uvarum $\mathrm{H} 107$ & H. vineae $\mathrm{G} 26$ & H. vineae $\mathrm{P} 38$ \\
\hline Oxide ${ }^{\mathrm{A}} \mathrm{b}$ & $29.7(1.2)$ & $30.4(2.1)$ & $33.7(3.2)$ & $26.9(3.4)$ \\
\hline Oxide $\mathrm{B}^{\mathrm{c}}$ & nd & nd & nd & nd \\
\hline Linalool & $20.0(0.9)$ & $40.4 *(3.9)$ & $47.4 *(3.4)$ & $38.2 *(5.3)$ \\
\hline Ho-trienol & $24.0(3.2)$ & $51.3 *(5.3)$ & $35.1 *(4.2)$ & $24.9 *(0.6)$ \\
\hline 2-Phenylethanol & $1890.2(43.4)$ & $3057.5 *(39.8)$ & $2747.8 *(26.8)$ & $2568.5 *(45.6)$ \\
\hline Oxide $C^{d}$ & nd & nd & nd & nd \\
\hline Oxide $\mathrm{D}^{\mathrm{e}}$ & nd & nd & nd & nd \\
\hline Terpineol & $53.3(3.4)$ & $67.2 *(4.7)$ & $65.1 *(1.2)$ & $54.5(3.9)$ \\
\hline Nerol & $24.6(2.8)$ & $25.8(1.1)$ & $23.4(3.1)$ & $26.3(1.2)$ \\
\hline Geraniol & $59.8(5.0)$ & $61.3(3.7)$ & $56.9(1.7)$ & $62.8(1.7)$ \\
\hline Diol $1^{\mathrm{f}}$ & $43.2(4.7)$ & $87.9 *(2.1)$ & $80.2 *(2.1)$ & $81.2 *(3.2)$ \\
\hline 4-Vinylphenol & $63.2(1.2)$ & $89.7 *(2.4)$ & $75.7 *(5.8)$ & $62.1(0.9)$ \\
\hline Endiolg $^{g}$ & nd & $58.8 *(2.1)$ & $52.0 *(3.4)$ & $34.1 *(4.2)$ \\
\hline Diol $2^{\mathrm{h}}$ & $12.0(0.6)$ & $13.4(0.9)$ & $7.8(2.6)$ & $10.1(0.9)$ \\
\hline 2-Phenylethyl acetate & $28.0(4.1)$ & $56.2 *(7.2)$ & $23.3(1.2)$ & $25.8(4.7)$ \\
\hline 2-Methoxy-4-vinylphenol & $89.0(6.1)$ & $103.0 *(5.3)$ & $105.4 *(6.5)$ & $94.1(2.9)$ \\
\hline
\end{tabular}

${ }^{a}$ Values in brackets represent standard deviation $(\mathrm{n}=3)$. ANOVA one factor, significant difference is indicated as * $(\mathrm{p}<0.05)$

${ }^{\mathrm{b}}$ cis-5-vinyltetrahydro-1,1,5-trimethyl-2-furanmethanol

${ }^{\mathrm{c}}$ trans-5-vinyltetrahydro-1,1,5-trimethyl-2-furanmethanol

d cis-6-vinyltetrahydro-2,2,6-trimethyl-2H-pyran-3-ol

e trans-6-vinyltetrahydro-2,2,6-trimethyl-2H-pyran-3-ol

f 2,6-Dimethyl-3,7-octadien-2,6-diol

g 2,6-Dimethyl-7-octene-2,6-diol

h 2,6-Dimethyl-2,7-octadien-1,6-diol

nd: not detected

yeasts (Swiegers et al., 2005). Our findings are similar to the observations of Fernández-González et al. (2003), who showed the ability of several wine yeasts to hydrolyse terpenoids, norisoprenoids and benzenoids glycosides. Among wine yeasts, $H$. uvarum was able to hydrolyse both glycoconjugated forms of pyranic and furanic oxides of linalool. Our results open the possibility for the use of these strains to improve the aromatic characteristics of the wines with regard to the liberation of terpenes. The production of wines with the addition of non-Saccharomyces strains has traditionally been related to high concentrations of vinyl-phenols (4-vinyl-phenol, 4-vinyl-guayacol), reaching concentrations of up to $1 \mathrm{mg} / \mathrm{L}$ (Sefton \& Williams, 1991; Gunata, 1993). The concentration of 4-vinyl-phenol in the tested wines was under $90 \mu \mathrm{g} / \mathrm{L}$, which enables the use of our selected strains in winemaking.

\section{CONCLUSIONS}

In the present study we characterised different Hanseniaspora strains previously isolated and stored in our laboratory. The strains were classified according to the molecular results and also were assayed to determine some biochemical activities of oenological interest. The yeasts basically showed moderated or no lipase, esterase, polygalacturonase, pectinase or xylanase activity but, interestingly, glycolitic ( $\beta$-xylosidase and $\beta$-glucosidase) activities were detected. These enzymatic activities can be used to enhance the quality of wine produced with $S$. cerevisiae strains.

This study contributes to the research on the role and potential exploitation of Hanseniaspora strains to release volatile terpenes in wines. The potential enzymatic activities shown by these isolates could be used profitably in specific vinification processes by consuming the remaining precursors of aromatic compounds. The two wineries supporting this study have decided to evaluate the use of the selected strains in further campaigns.

\section{LITERATURE CITED}

Arévalo, M., Úbeda, J.F. \& Briones, A.I., 2007. Glucosidase activity in wine yeasts: Application in enology. Enzyme Microb. Technol. 40, 420-425.

Arroyo-López, F.N., Querol, A., Bautista Gallego, J. \& Garrido Fernández, A., 2008. Role of yeasts in table olive production. Int. J. Food Microbiol. 128, 189-196. 
Arroyo-López, F.N., Durán-Quintana, M.C., Ruiz-Barba, J.L., Querol, A. \& Garrido-Fernández, A., 2006. Use of molecular methods for the identification of yeast associated with table olives. Food Microbiol. 23, 791-796.

Branco, P., Monteiro, M., Moura, P. \& Albergaria, H., 2012. Survival rate of wine-related yeasts during alcoholic fermentation assessed by direct live/ dead staining combined with fluorescence in situ hybridization. Int. J. Food Microbiol. 158, 49-57.

Cadez, N., Raspor, P., De Cock, A.W.A.M., Boekhout, T. \& Smith, M.T., 2002. Molecular identification and genetic diversity within species of genera Hanseniaspora and Kloeckera. FEMS Yeast Res. 1, 279-289.

Cadez, N., Poot, G.A., Raspor, P. \& Smith, M.T., 2003. Hanseniaspora meyeri sp. nov., Hanseniaspora clermontiae sp. nov., Hanseniaspora lachancei sp. nov. and Hanseniaspora opuntiae sp. nov., novel apiculate yeast species. Int. J. Syst. Evol. Microbiol. 53, 1671-1680.

Charoenchai, C., Fleet, G.H., Henschke, P.A. and Todd B.E.N., 1997. Screening of non-Saccharomyces wine yeasts for the presence of extracellular hydrolytic enzymes. Aust. J. Grape Wine Res. 3, 2-8.

Ciani, M. \& Comitini, F., 2011. Non-Saccharomyces wine yeasts have a promising role in biotechnological approaches to winemaking. Ann. Microbiol. 61, 25-32.

Dubourdieu, D.P., Darriet, P., Chatonnet, F. \& Boidron, J.M., 1989. Proc. Fourth Int. Enology Symp., Bourdeaux (France), June. pp. 151 - 159.

Esteve-Zarzoso, B., Belloch, C., Uruburu, F. \& Querol, A., 1999. Identification of yeasts by RFLP analysis of the 5.85 rRNA gene and the two ribosomal internal transcribed spacers. Int. J. Syst. Bacteriol. 49, 329-337.

Fernández, M., Úbeda, J.F. \& Briones, A.I., 2000. Typing of nonSaccharomyces yeasts with enzymatic activities of interest in wine-making. Int. J. Food Microbiol. 59, 29-36.

Fernández-González, M., Di Stefano, R. \& Briones, A., 2003. Hydrolysis and transformation of terpene glycosides from muscat must by different yeast species. Food Microbiol. 20, 35-41.

Ferreira, A.M., Clímaco, M.C. \& Faría, A.M., 2001. The role of nonSaccharomyces species in releasing glycosidic bound fraction of grape aroma components - A preliminary study. J. Appl. Microbiol. 91, 67-71.

Gil, J.V., Mateo, J.J, Jiménez, M., Pastor, A. \& Huerta. T., 1996. Aroma compounds in wine as influences by apiculate yeasts. J. Food Sci. 61, 12471249 .

Grimaldi, A., Bartowsky, E. \& Jiranek, V., 2005. A survey of glycosidase activities of commercial wine strains of Oenococcus oeni. Int. J. Food Microbiol. 105, 233-234.

Gueguen, Y., Chemardin, P., Labrot, P., Arnaud, A. \& Galzy, P., 1997. Purification and characterization of an intracellular $\beta$-glucosidase from a new strain of Leuconostoc mesenteroides isolated from cassava. J. Appl. Microbiol. 82, 469-476.

Guillamón, J.M., Sabaté, J., Barrio, E., Cano, J. \& Querol, A., 1998. Rapid identification of wine yeasts species based on RFLP analysis of the ribosomal ITS regions. Arch. Microbiol. 169, 387-392.

Gunata, Z., 1993. Etude et exploitation par voie enzymatize des precurseurs d'arômes du raisin de nature glycosidique. Revue des Oenologues 74, 22 27

Gunata, Z., Bitteur, S., Brillouet, J.-M., Bayonove, C. \& Cordonnier, R., 1988. Sequential enzymic hydrolysis of potentially aromatic glycosides from grape. Carbohydr. Res. 184(C), 139-149.

Heard, G.M. \& Fleet, G.H., 1986. Evaluation of selective media for enumeration of yeasts during wine fermentation. J. Appl. Bacteriol. 60, $477-$ 481.
Hernández, A., Martín, A., Aranda, E., Pérez Nevado, F. \& Córdoba, M.G., 2007. Identification and characterization of yeasts isolated from the elaboration of seasoned green table olives. Food Microbiol. 24, 346-351.

Jindamorakot, S., Ninomiya, S., Limtong, S., Yongmanitchai, W., Tuntirungkij, M., Potacharoen, W., Tanaka, K., Kawasaki, H. \& Nakase, T., 2009. Three new species of bipolar budding yeasts of the genus Hanseniaspora and its anamorph Kloeckera isolated in Thailand. FEMS Yeast Res. 9, 1327-1337.

Kurtzman, C., Fell, J.W. \& Boekhout, T., 2011. The yeasts: A taxonomic study, 5 th ed. Elsevier, London.

Kurtzman, C.P. \& Robnett, C.J., 1998. Identification and phylogeny of ascomycetous yeast from analysis of nuclear large subunit (26S) ribosomal DNA partial sequences. Antonie van Leeuwenhoek 73, 331-371.

Kurtzman, C.P., O’Donell, K. \& Smith, M.T., 1994. Phylogeny of the yeast genera Hanseniaspora (anamorph Kloeckera), Dekkera (anamorph Brettanomyces), and Eeniella as inferred from partial 26s ribosomal DNA nucleotide sequences. Int. J. Syst. Bacteriol. 44, 781-786.

López de Lerma, N. \& Peinado, R.A., 2011. Use of two osmoethanol tolerant yeast strains to ferment must from Tempranillo dried grapes. Effect on wine composition. Int. J. Food Microbiol. 145, 342-348.

Madrigal, T., Maicas, S. \& Mateo, J.J., 2013. Glucose and ethanol tolerant enzymes produced by Pichia (Wickerhamomyces) isolates from enological ecosystems. Am. J. Enol. Vitic. 64, 126-133.

Maicas, S. \& Mateo, J.J. 2005. Hydrolysis of terpenyl glycosides in grape juice and other fruit juices: A review. Appl. Microbiol. Biotechnol. 67, 322355 .

Manzanares, P., Ramon, D. \& Querol, A., 1999. Screening of nonSaccharomyces wine yeasts for the production of $\beta$-D-xylosidase activity. Int. J. Food Microbiol. 46, 105-112.

Mateo, J.J. \& Di Stefano, R., 1997. Description of the $\beta$-glucosidase activity of wine yeasts. Food Microbiol. 14, 583-591.

Mateo, J.J., Jiménez, M., Huerta, T. \& Pastor, A., 1991. Contribution of different yeasts isolated from musts of Monastrell grapes to the aroma of wine. Int. J. Food Microbiol. 14, 153-160.

Mateo, J.J., Jiménez, M., Huerta, T. \& Pastor, A., 1992. Comparison of volatiles produced by four Saccharomyces strains isolated from Monastrell musts. Am. J. Enol. Vitic. 43, 206-209.

Mateo, J.J., Peris, L., Ibañez, C. \& Maicas, S., 2011. Characterization of glycolytic activities from non-Saccharomyces yeasts isolated from Bobal musts. J. Ind. Microbiol. Biotechnol. 38, 347-354

Moreira, N., Mendes, F., Hogg, T. \& Vasconcelos, I., 2005. Alcohols, esters and heavy sulphur compounds production by pure and mixed cultures of apiculate wine yeasts. Int. J. Food Microbiol. 103, 285-294.

Oliveira, J.M., Oliveira, P., Baumes, R.L. \& Maia, M.O., 2008. Volatile and glycosidically bound composition of Loureiro and Alvarinho wines. Food Sci. Technol. Int. 14, 341-353.

Oliveira, R.Q., Rosa, C.A., Uetanabaro, A.P., Azeredo, A., Neto, A.G. \& Assis, S.A., 2009. Polygalacturonase secreted by yeasts from Brazilian semiarid environments. Int. J. Food Sci. Nutr. 60(Suppl. 7), 72-80.

Pando, R., Lastra, A. \& Suarez, B., 2012. Screening of enzymatic activities in non-Saccharomyces cider yeast. J. Food Biochem. 36, 683-689.

Paraggio, M., 2004. Biodiversity of a natural population of Saccharomyces cerevisiae and Hanseniaspora uvarum from Aglianico del Vulture. Food Technol. Biotechnol. 42, 165-168.

Restuccia, C., Pulvirenti, A., Caggia, C. \& Giudici, P., 2002. A $\beta$-glucosidase positive strain of Saccharomyces cerevisiae isolated from grape must. Ann. Microbiol. 52, 47-53. 
Rodríguez, F., Arroyo, F.N., Lopez, A., Bautista, J. \& Garrido, A., 2010. Lipolytic activity of the yeast species associated with the fermentation/storage phase of ripe olive processing. Food Microbiol. 27, 604-612.

Rojas, V., Gil, J.V., Pinaga, F. \& Manzanares, P., 2001. Studies on acetate ester production by non-Saccharomyces wine yeasts. Int. J. Food Microbiol. $70,283-289$

Romano, P., Fiore, C., Paraggio, M., Caruso, M. \& Capece, A., 2003. Function of yeast species and strains in wine flavor. Int. J. Food Microbiol. 86, 169-180.

Romero, A.M., Mateo, J.J. \& Maicas, S., 2012. Characterization of an ethanol tolerant 1,4- $\beta$-xylosidase produced by Pichia membranifaciens. Lett. Appl. Microbiol. 55, 354-361.

Sefton, M.A. \& Williams, P.J., 1991. Generation of oxidation artifacts during the hydrolysis of norisoprenoid glycosides by fungal enzyme preparations. J. Agric. Food Chem. 39, 1994-1997.

Strauss, M.L.A., Jolly, N.P., Lambrechts, M.G. \& Van Rensburg, P., 2001. Screening for the production of extracellular hydrolytic enzymes by nonSaccharomyces wine yeasts. J. Appl. Microbiol. 91, 182-190.
Swangkeaw, J., Vichitphan, S., Butzke, C.E. \& Vichitphan, K., 2011. Characterization of $\beta$-glucosidases from Hanseniaspora sp. and Pichia anomala with potentially aroma-enhancing capabilities in juice and wine. World J. Microbiol. Biotechnol. 27, 423-430.

Swiegers, J.H., Bartowsky, E.J., Henschke, P.A. \& Pretorius, I.S., 2005. Yeast and bacterial modulation of wine aroma and flavour. Austr. J. Grape Wine Res. 11, 139-173.

Ubeda, J. \& Briones, A., 2000. Characterization of differences in the formation of volatiles during fermentation within synthetic and grape musts by wild Saccharomyces strains. LWT - Food Sci. Technol. 33, 408-414.

Ugliano, M., 2009. Enzymes in winemaking. In: Moreno-Arribas, M.V. \& Polo, C. (eds). Wine chemistry and biochemistry. Springer Science-Business Media, Adelaide. pp. $103-126$

Viana, F., Gil, J.V., Vallés, S. \& Manzanares, P., 2009. Increasing the levels of 2-phenylethyl acetate in wine through the use of a mixed culture of Hanseniaspora osmophila and Saccharomyces cerevisiae. Int. J. Food. Microbiol. 135, 6-75. 